\title{
Preliminary Studies on the Effect of a Permanent Cover Crop and Root Pruning on an Irrigated Colombar Vineyard
}

\author{
D. SAAYMAN AND L. VAN HUYSSTEEN
}

Viticultural and Oenological Research Institute, Private Bag X5026, Stellenbosch 7600, Republic of South Africa.

The authors wish to express their sincere gratitude to Mr G. J. J. Albertse for his technical assistance in this trial.

\begin{abstract}
An experiment was conducted in the Olifantsrivier irrigation area to assess the effect of different cultivation treatments, such as clean cultivation, a permanent cover crop and of root pruning by means of deep ripping, on the growth and yield of a flood irrigated, ungrafted Colombar vineyard.

The best vine performance was obtained with clean cultivation. Although a cover crop plus deep cultivation improved water infiltration, competition of the permanent cover crop seriously suppressed vine growth and yield, and also caused a notable decrease in the nitrogen status of the vines. There were indications that severe root pruning by means of deep ripping increased the negative effect of the permanent cover crop on vine performance.

Clean cultivation remains an effective way of weed control provided there is no soil compaction hazard and it is economically feasible.
\end{abstract}

Under irrigation, weeds continue to grow during the growing season of the vine. Conventional clean cultivation of vineyards can control weeds effectively, but can lead to the deterioration of soil structure on certain soils and, therefore, to a low water infiltration rate (Van Huyssteen \& Weber, 1980a; 1980b). A cover of dead plant material on the soil surface as well as a permanent cover crop are effective in maintaining soil structure and improving water infiltration (Christensen \& Lynn, 1969; Black, 1973; Koshi \& Fryrear, 1973; Van Doren \& Triplett, 1973; Meyer \& Cuinier, 1977). However, opinions differ about the effect of a permanent cover crop on vine performance. Some workers found no effect of permanent cover crops on grape yield and quality (Meyer \& Cuinier, 1977; Schröder, Zakosek \& Böll, 1978). However, on poor soils and in regions with insufficient rainfall, only a temporary cover crop is recommended by Meyer \& Cuinier (1977). With temporary as well as permanent cover crops, deep rooted vines and the addition of sufficient organic matter are prerequisites to overcome the competition of the cover crops. Altweg \& Koblet (1976) found that because of competition for nutrients, shoot growth of vines under a cover crop was 25 per cent less than that of vines in a weed free vineyard. Byrne \& Howell (1978) also found that a weed cover affected the nutritional status of vines and resulted in smaller vines and a very large reduction in yield.

The effect of root pruning by means of deep cultivation was tested in some countries with divergent results. Kaiser (1966) found intensive regrowth of roots after pruning but showed that the roots should not be cut closer than $40-50 \mathrm{~cm}$ from the vine. However, despite an intensive regrowth of roots, no improvement of shoot growth was noted.

Litvinov (1967) recommended that deep cultivation should not be done in vineyards younger than six years and that it should be repeated only after two to three years. Oprea, Severin \& Taloi (1967) concluded that only part of the root system should be cut in order to ensure an adequate supply of nutrients and water to the vines during regrowth. Melkonjan, Mkrtcjan \& Davtjan (1968) reported that deep cultivation in every second interrow increased yield by 16,7 per cent, while deep cultivation in every interrow increased yield with 34,9 per cent on a soil with a definite compacted layer. Deep cultivation also improved plant vigour. Litvinov \& Beskrovnyi (1979) found improved productivity on plots deeply cultivated in autumn. On the other hand, Ryabchun (1974) found a gradual decrease in regrowth of roots after repeated deep cultivations.

The aim of this study was to assess the effect of a permanent cover crop and severe root pruning on vine performance under conditions of intensive irrigation.

\section{MATERIALS AND METHODS}

The trial was done in an existing 13 year old, ungrafted Vitis vinifera L var. Colombar vineyard, spaced $3,0 \times 1,8 \mathrm{~m}$ and trained on a $1 \mathrm{~m}$ Y-trellis as described by Zeeman (1981), on the V O R I experimental farm near Lutzville, Olifantsrivier valley. This area falls in Region V (Winkler et al., 1974), has a mean annual rainfall of c. $150 \mathrm{~mm}$ of which only $40 \mathrm{~mm}$ falls during the growing season, resulting in an irrigation requirement of c. $675 \mathrm{~mm}$ for this period (Van Zyl, 1981). The soil is deep, red, calcareous (Hutton: Maitengwe, according to MacVicar \& Soil Survey Staff, 1977), representative of the so-called 'Karoo soils' of this area. Although the soil was not deep ploughed before planting, inspection of profile pits showed no obviously compacted layer to a depth of $90 \mathrm{~cm}$. The analyses data for the soil concerned are shown in Table 1.

TABLE 1

Analytical data of the Hutton: Maitengwe soil, Lutzville

\begin{tabular}{|c|c|c|c|c|c|c|c|c|c|c|c|c|c|c|}
\hline Horison & $\begin{array}{l}\text { Depth } \\
(\mathrm{cm})\end{array}$ & $\begin{array}{l}\mathrm{pH} \\
(\mathrm{KCI})\end{array}$ & $\begin{array}{l}\text { R } \\
\text { (ohm) }\end{array}$ & $\begin{array}{l}\text { P } \\
(\mathrm{ppm})\end{array}$ & $\begin{array}{l}\text { Exch } \\
\text { K }\end{array}$ & $\begin{array}{l}\text { geable } \\
\mathrm{Na}\end{array}$ & $\begin{array}{l}\text { tions ( } \\
\mathrm{Ca}\end{array}$ & $\begin{array}{r}\mathrm{e \%}) \\
\mathrm{Mg}\end{array}$ & $\begin{array}{l}\text { T-value } \\
(\mathrm{me} \%)\end{array}$ & $\begin{array}{l}\text { C.Sa } \\
(\%)\end{array}$ & $\begin{array}{l}\text { Med.Sa } \\
(\%)\end{array}$ & $\begin{array}{l}\text { F.Sa } \\
(\%)\end{array}$ & $\begin{array}{l}\text { Silt } \\
(\%)\end{array}$ & $\begin{array}{l}\text { Clay } \\
(\%)\end{array}$ \\
\hline Al.1 & $0 / 15$ & 7,5 & 801 & 326 & 0,82 & 0,26 & 14,71 & 3,31 & 8,92 & 4,0 & 11,4 & 65,1 & 5,5 & 11,0 \\
\hline B1. 1 & $15 / 28$ & 7,3 & 812 & 218 & 0,82 & 0,28 & 10,83 & 3,68 & 11,07 & 4,2 & 11,6 & 67,9 & 4,9 & 10,1 \\
\hline B1. 2 & $28 / 65$ & 7,4 & 708 & 293 & 0,65 & 0,50 & 4,70 & 5,35 & 11,60 & 4,3 & 10,4 & 77,1 & 1,2 & 3,9 \\
\hline B1. 3 & $65 / 100$ & 7,0 & 490 & 341 & 0,53 & 2,70 & 4,75 & 4,04 & 9,46 & 5,3 & 12,4 & 66,8 & 8,5 & 6,4 \\
\hline
\end{tabular}


The experiment was laid out as a randomised block design comprising three cultivation treatments and three replications. Plots contained 24 data vines each and were separated on each side by one border row. The vines were pruned to 20-25 two-bud spurs per vine (c. 40800 buds/ha), flood irrigated every four weeks during the growing season and received $600 \mathrm{~kg} \mathrm{3:1:5(26)}$ fertiliser mixture plus $180 \mathrm{~kg}$ urea per hectare each year. The vineyard, which was clean cultivated since planting, received the following cultivation treatments starting in 1972:

T1: Permanent cover crop: Two sub-terranean, winter growing clover (Medicago trancatula) varieties viz. Cyprus and Jemalong, were sown as a 1:1 mixture during early autumn. However, Bromus wildenowii grass invaded the plots, and from 1975 there was hardly any clover left. This natural grass was then kept as a cover crop for the duration of the trial and was cut with a bush cutter each time a regrowth height of $c .20 \mathrm{~cm}$ was reached, amounting to 7-10 cuttings during the growing season.

T2: Permanent cover crop plus deep cultivation: Same as $\mathrm{T} 1$ except that during early autumn, deep cultivation was done on the moist soil with a two-tined ripper in every second interrow, $60 \mathrm{~cm}$ from the vines to a depth of $30 \mathrm{~cm}$. In the following season each tine was moved $30 \mathrm{~cm}$ towards the middle of the implement in order to cut the roots in the same interrow $90 \mathrm{~cm}$ from the vines. This procedure was repeated each year so that after four years the whole interrow soil volume was treated in this manner. Each year the implement was also set progressively deeper to reach a maximum depth of about 60 $\mathrm{cm}$ in the middle of the row after four years. At the same time the interrow space was loosened and the roots were cut in exactly the reverse order in the adjacent interrows. After four years the whole procedure was repeated but the order of the rip treatments for the interrows was reversed.

T3: Clean cultivation: A shallow $20-30 \mathrm{~cm}$ deep trench furrow was ploughed each winter in alternate rows, and prunings were ploughed under in these furrows. Natural weeds were allowed to grow during winter and were disced into the soil just before budding. During the growing season the soil was cultivated with a tiller after each irrigation and whenever it was necessary to control weeds a total of 7 to 10 cultivations per season.

Pruning mass and crop yield were measured each year and total soluble solids and total acidity were determined in the must. Roots exposed in the walls of profile pits dug perpendicularly to vine rows were mapped during 1972 and 1978. Leaf blades opposite bunch positions were collected during four seasons at berry set stage and analysed for nitrogen, phosphorous and potassium, using standard V O R I procedures.

The bulk density of the soil was determined at different depths before commencement of the trial by means of cylinders and drop hammer and again during 1978, using a neutron/gamma moisture/density probe. Water infiltration rate was measured in $2 \times 2 \mathrm{~m}$ earthern wall dams between vine rows by filling them rapidly to a depth of $200 \mathrm{~mm}$.

\section{RESULTS AND DISCUSSION}

The effect of different cultivation practices on shoot mass is depicted in Fig. 1. Although the shoot mass was initially similar for all treatments, a definite and consistent pattern evolved since the $1973 / 74$ season, three years after the commencement of the trial. The clean cultivation treatment (T3) did not induce a significantly more vigorous shoot growth than the permanent cover crop treatment (T1), but had a significantly better effect than the permanent cover crop plus deep cultivation treatment (T2), the latter probably because of the increased negative effect of root pruning. During the last two seasons, vines on the clean cultivation plots also had a significantly higher shoot mass than vines on the permanent cover crop plots (T1). Shoot mass declined steadily during the last five seasons for all treatments. The reason for this decline may possibly be ascribed to the fact that the vines were ungrafted and, therefore, affected by phylloxera and nematodes.

Yield differences between treatments followed a similar pattern to that of shoot mass (Fig. 2). Although differences in yield between treatments were not statistically significant, except during the $1978 / 79$ season, the tendency towards a better performance of the vines on clean cultivated plots was consistent and a yield of 7,9 $\mathrm{kg} /$ vine $(=14,3 \mathrm{t} / \mathrm{ha})$ higher than the other treatments during 1980/81, was obtained. The lack of significant differences in yield can be ascribed to a large variation (Coefficient of variation usually $>20$ per cent) compared to that of shoot mass (Coefficient of variation $<$ 20 per cent). Unlike shoot mass, yield did not show such a prominent decline over the successive seasons.

No significant effects of treatment on total titratable acidity and total soluble solids of the must were found (Table 2). However, there were indications that must from clean cultivated plots had a higher TSS at harvest than those from the other treatments.

TABLE 2

Effect of cultivation treatments on the total soluble solids (TSS) and total titratable acidity (TTA) concentrations in Colombar must, Lutzville.

\begin{tabular}{|c|c|c|c|c|c|c|c|}
\hline \multirow[b]{2}{*}{$\begin{array}{l}\text { Treat- } \\
\text { ment }\end{array}$} & \multirow[b]{2}{*}{$\begin{array}{l}\text { Component } \\
\text { measured }\end{array}$} & \multicolumn{5}{|c|}{ Season } & \multirow[b]{2}{*}{ Mean } \\
\hline & & $\begin{array}{l}1975 / \\
76\end{array}$ & $\begin{array}{l}1976 / \\
77\end{array}$ & $\begin{array}{l}1977 / \\
78\end{array}$ & $\begin{array}{l}1978 / \\
79\end{array}$ & $\begin{array}{l}1979 / \\
80\end{array}$ & \\
\hline \multirow[t]{2}{*}{$\mathrm{T} 1$} & $\operatorname{TSS}\left({ }^{\circ} \mathbf{B}\right)$ & 21,0 & 19,6 & 20,7 & 20,7 & 20,5 & 20,5 \\
\hline & $\mathrm{TTA}(\mathrm{g} / \mathrm{l})$ & - & 6,8 & - & 5,8 & - & 6,3 \\
\hline \multirow[t]{2}{*}{$\mathrm{T} 2$} & $\operatorname{TSS}\left({ }^{\circ} \mathrm{B}\right)$ & 21,7 & 20,2 & 20,0 & 21,0 & 20,8 & 20,7 \\
\hline & $\mathrm{TTA}(\mathrm{g} / \mathrm{l})$ & - & 6,6 & - & 6,2 & - & 6,4 \\
\hline \multirow[t]{2}{*}{ T3 } & $\operatorname{TSS}\left({ }^{\circ} \mathrm{B}\right)$ & 22,0 & 20,1 & 21,1 & 21,3 & 21,4 & 21,2 \\
\hline & $\mathrm{TTA}(\mathrm{g} / \mathrm{l})$ & - & 6,9 & - & 6,5 & - & 6,7 \\
\hline \multirow{2}{*}{$\begin{array}{l}\text { Signifi- } \\
\text { cance }\end{array}$} & TSS & NS & NS & NS & NS & NS & - \\
\hline & TTA & - & NS & - & NS & - & - \\
\hline
\end{tabular}

T1 - Permanent cover crop

T2 - Permanent cover crop plus deep cultivation

T3 - Clean cultivation

NS: Not significant 


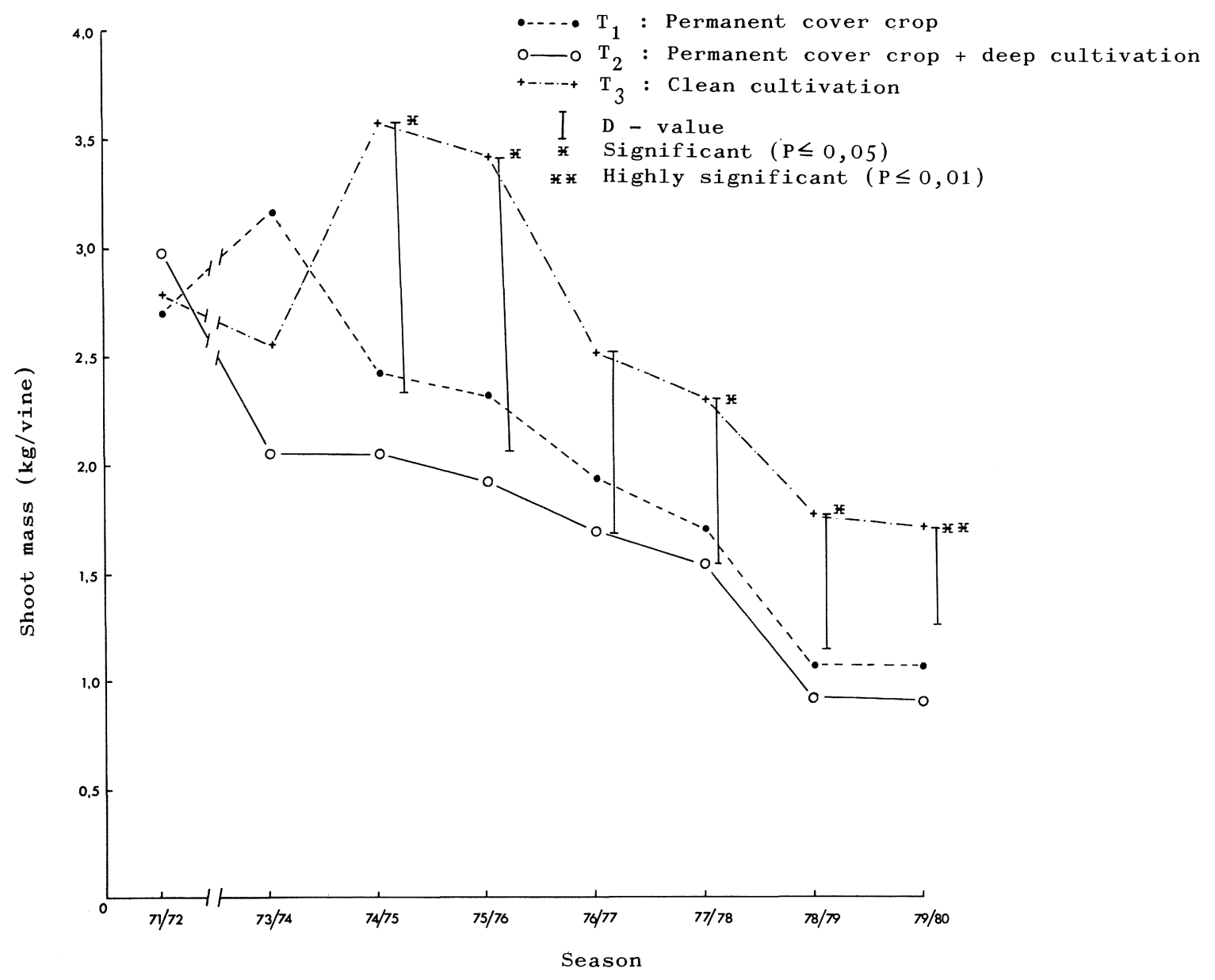

Fig. 1

Effect of different cultivation methods on shoot mass of Colombar, Lutzville.

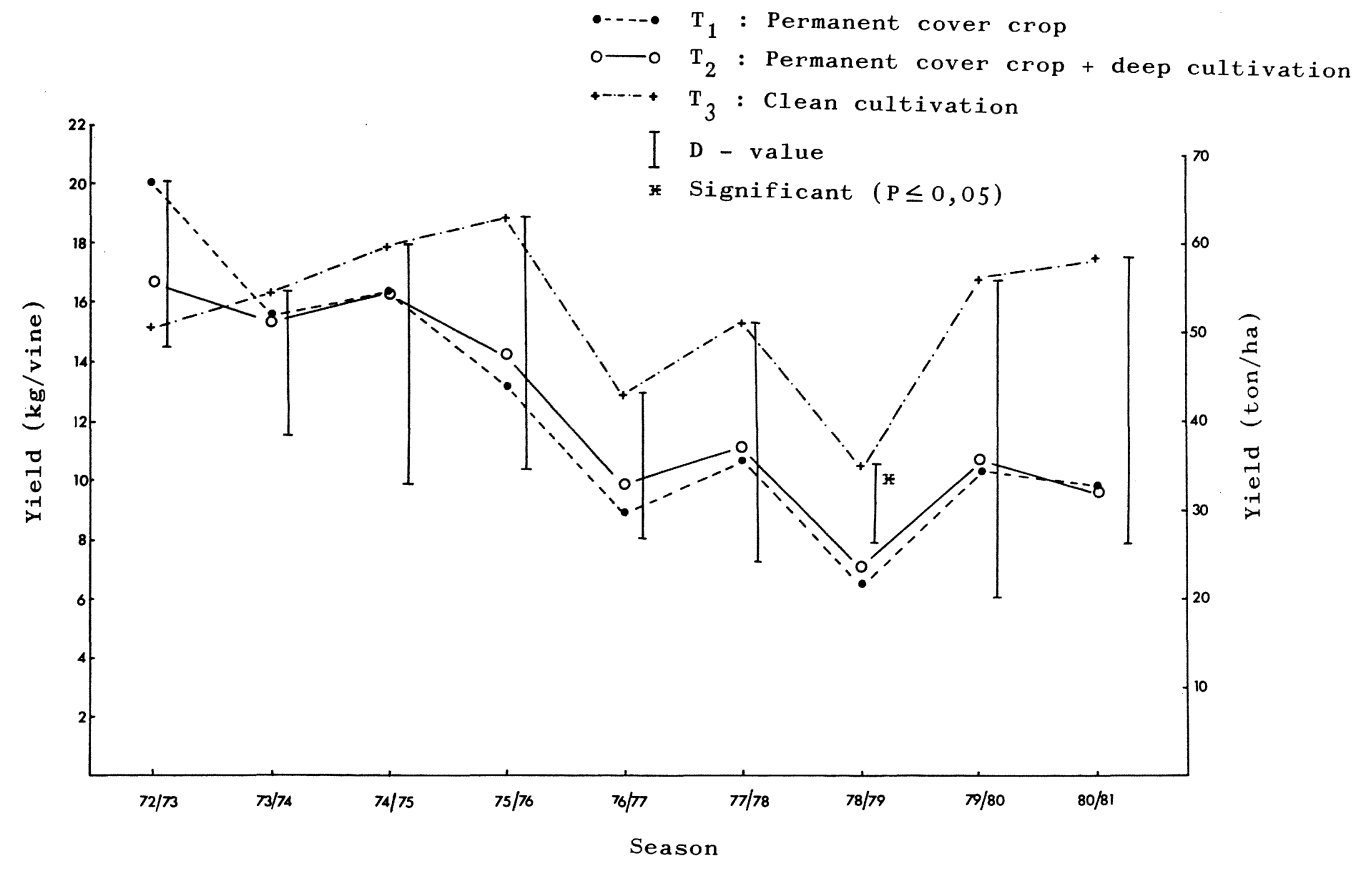

Fig. 2

Effect of cultivation on yield of Colombar, Lutzville.

S. Afr. J. Enol. Vitic., Vol. 4. No. 1. 1983 
The nitrogen, phosphorus and potassium contents of leaf blades from the various treatment plots are shown in Table 3. Clean cultivation tended to induce higher nitrogen $(\mathrm{N})$ concentrations in leaves than the cover crop (T1) and cover crop plus deep cultivation (T2) treatments. These differences in $\mathrm{N}$ concentrations were found to be significant in the instances where statistical analyses could be done. According to Conradie (1981), the $\mathrm{N}$-content of leaf blades from Chenin blanc/99R grown in sand culture was 2,9 per cent, while the norm for table grapes is 1,6 - 2,4 per cent (Beyers, 1962). From these values and those in Table 3 it appears, therefore, that the trial vineyard was generally undernourished as far as $\mathrm{N}$ was concerned, in spite of a total of $135 \mathrm{~kg} \mathrm{~N} / \mathrm{ha}$ applied per season, which may be regarded as more than sufficient for high producing vineyards (Champagnol, 1978; Christensen, Kasimatis \& Jensen, 1978; Marcelin, 1979). The general low N concentration in leaves was probably due to the use of urea as main $\mathrm{N}$ source on this alkaline soil and to the flood irrigation practice, resulting in volatilisation and/or leaching losses of N. However, the consistently higher $\mathrm{N}$ content of leaves from clean cultivated vines as well as their better performance (Fig. 1) could still partly be ascribed to better $\mathrm{N}$ nutrition (the $\mathrm{N}$ concentration in leaf blades being 20 per cent and 13 per cent higher than those in leaves from $\mathrm{T} 2$ and $\mathrm{T} 1$ plots respectively), and undoubtedly also to a better water supply in the absence of weed competition, as was found by Altweg \& Koblet (1976), Byrne \& Howell (1978) and Van Huyssteen \& Weber (1980c).

Root pruning by means of deep cultivation in each interrow (T2 treatment) had a much less marked effect on $\mathrm{N}$ nutrition that cover crops, but there were indications that root pruning was too severe and seems to have increased the negative competition effect of a permanent cover crop (T1 treatment).

TABLE 3

Effect of cultivation treatments on the main macro element concentration in Colombar leaf blades, Lutzville.

\begin{tabular}{|c|c|c|c|c|c|}
\hline \multirow[b]{2}{*}{ Element } & \multirow[b]{2}{*}{ Season } & \multicolumn{3}{|c|}{ Treatment } & \multirow{2}{*}{$\begin{array}{l}\text { Significance } \\
\text { (D-value) }\end{array}$} \\
\hline & & $\mathrm{T} 1$ & $\mathrm{~T} 2$ & T3 & \\
\hline \multirow{5}{*}{$\mathrm{N}(\%)$} & $1975 / 76$ & 1,87 & 1,72 & 2,04 & $\mathrm{a}$ \\
\hline & $1976 / 77$ & 1,25 & 1,15 & 1,44 & $\mathrm{a}$ \\
\hline & $1977 / 78$ & 1,64 & 1,62 & 1,92 & $*(0,26)$ \\
\hline & $1978 / 79$ & 1,55 & 1,46 & 1,76 & $*(0,18)$ \\
\hline & Mean & 1,58 & 1,49 & 1,79 & - \\
\hline \multirow{5}{*}{$\mathrm{P}(\%)$} & $1975 / 76$ & 0,18 & 0,19 & 0,17 & $\mathrm{a}$ \\
\hline & $1976 / 77$ & 0,22 & 0,17 & 0,18 & $\mathrm{a}$ \\
\hline & $1977 / 78$ & 0,22 & 0,22 & 0,22 & NS \\
\hline & $1978 / 79$ & 0,26 & 0,26 & 0,19 & NS \\
\hline & Mean & 0,22 & 0,21 & 0,19 & - \\
\hline \multirow{5}{*}{$\mathrm{K}(\%)$} & $1975 / 76$ & 0,50 & 0,62 & 0,62 & $\mathrm{a}$ \\
\hline & $1976 / 77$ & 0,62 & 0,57 & 0,56 & $\mathrm{a}$ \\
\hline & $1977 / 78$ & 0,57 & 0,56 & 0,63 & NS \\
\hline & $1978 / 79$ & 0,63 & 0,55 & 0,52 & $*(0,09)$ \\
\hline & Mean & 0,58 & 0,57 & 0,58 & - \\
\hline
\end{tabular}

T1 - Permanent cover crop

T2 - Permanent cover crop plus deep cultivation

T3 - Clean cultivation

a - Samples were pooled, consequently no statistical analyses were possible

- Significant $(\mathrm{P} \leq 0,05)$

NS - Not significant

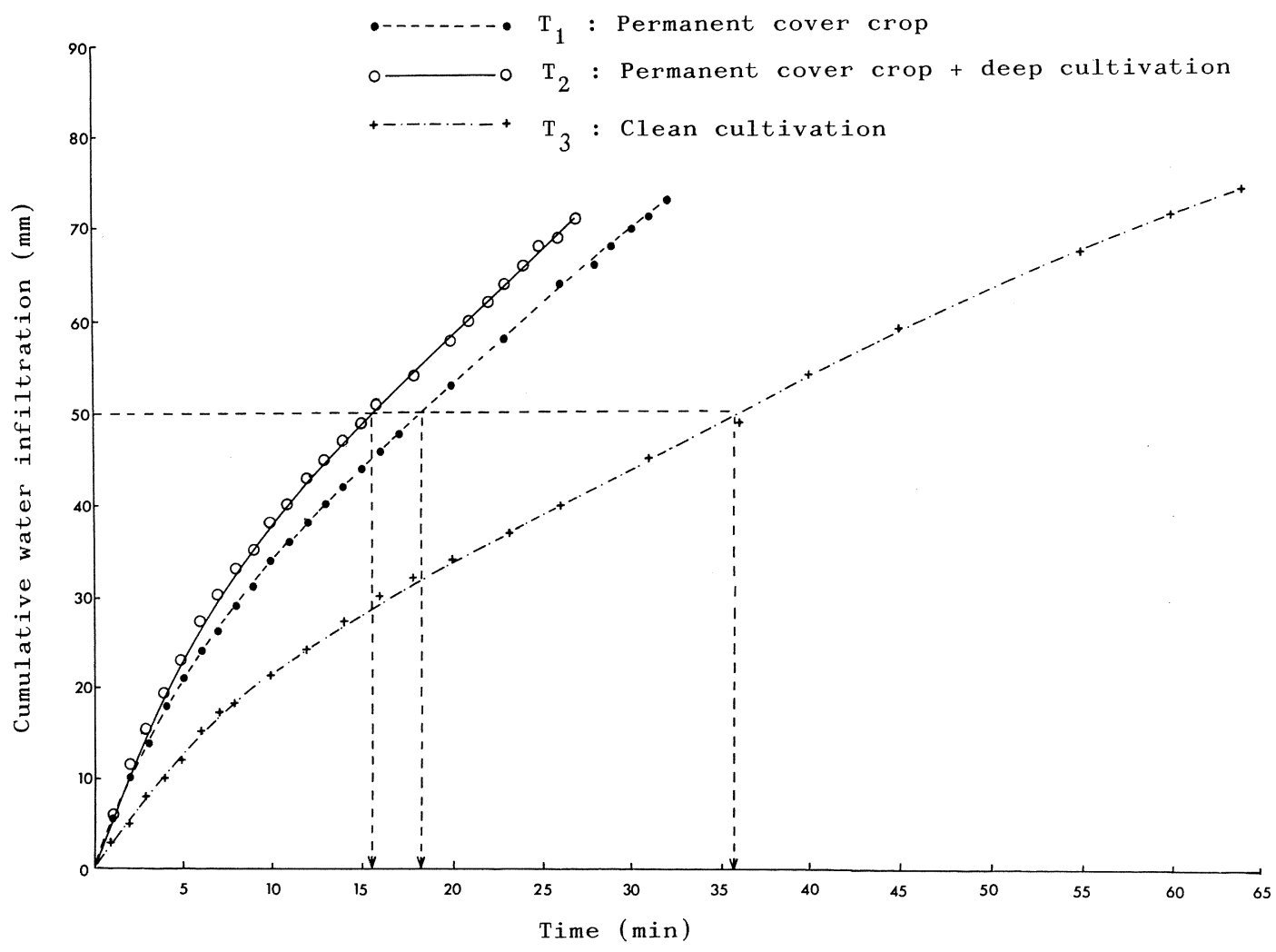

Fig. 3

Cumulative water infiltration on differently cultivated plots. 


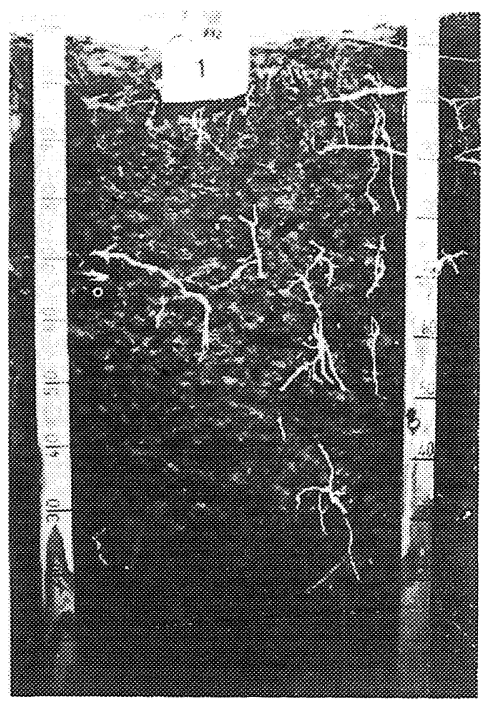

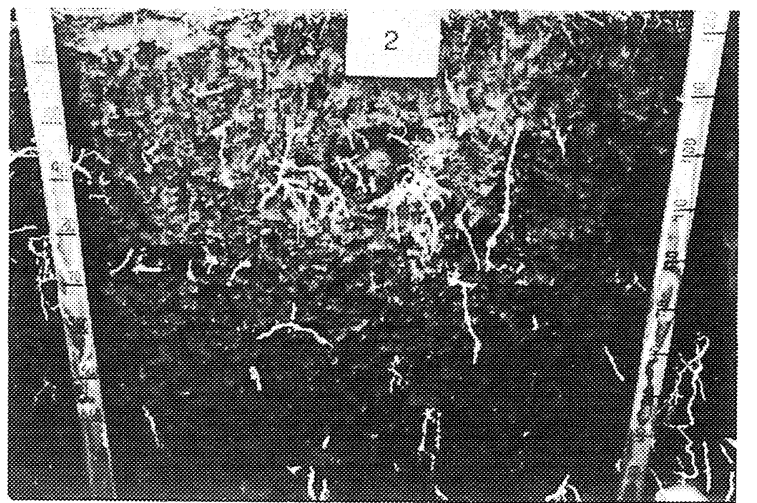

(a)

1, 2, 3: south, west and north facing sides respectively, of a representative profile pit.

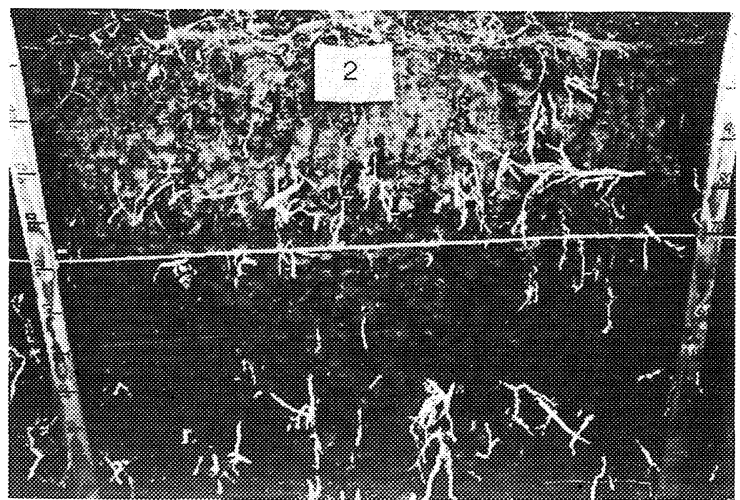

(b)

4: Approximate working depth of ripper tines.

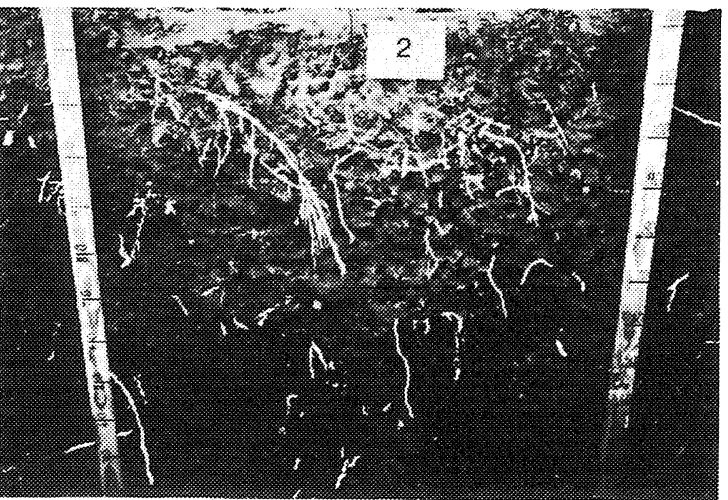

(c)
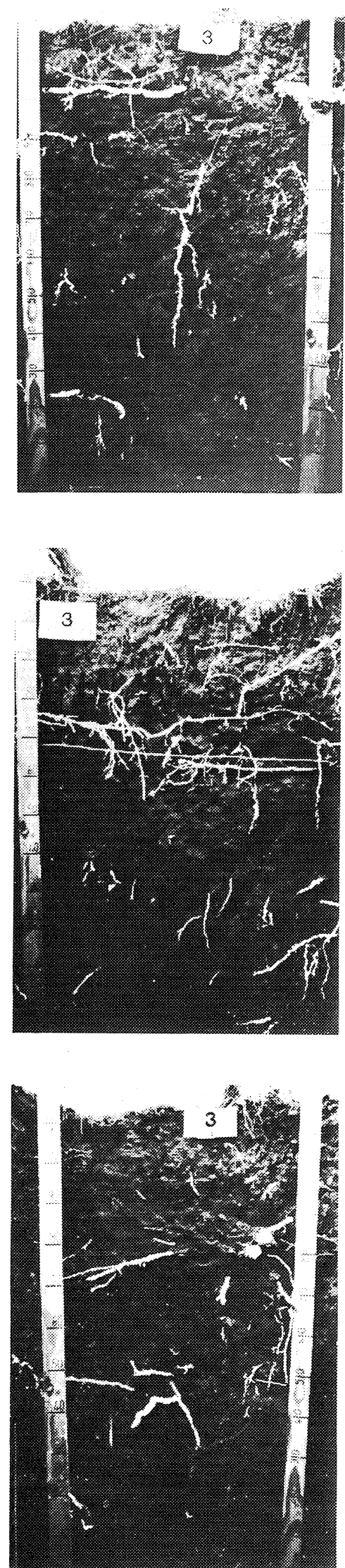

PLATE 1

Distribution of Colombar roots under (a) permanent cover crop, (b) permanent cover crop plus annual deep cultivation and (c) clean cultivation, Lutzville. 
Water infiltration rates (Fig. 3), indicate that a permanent cover crop as well as a permanent cover crop plus deep cultivation had a beneficial effect on soil physical conditions. The infiltration time for $50 \mathrm{~mm}$ water was 15,5 min on T2 plots, whereas the corresponding periods were $18,5 \mathrm{~min}$ and $35,7 \mathrm{~min}$ for $\mathrm{T} 1$ and $\mathrm{T} 3$ plots respectively.

The beneficial effect of a cover crop on water infiltration is in accordance with the findings of Van Huyssteen \& Weber (1980a) under dry land conditions, which showed that the continuity of the soil pores is destroyed by the regular disturbance of the soil under clean cultivation, resulting in a slower infiltration rate. However, this effect was not so severe as to inhibit water infiltration sufficiently in this soil. Clean cultivation, therefore, still remains an effective and practical means of weed control provided there is no compaction and that it is economically feasible, as was also concluded by Van Huyssteen \& Weber (1980c).

Bulk density measurements during 1972 and 1978 showed that the soil had no compacted layers up to a depth of $120 \mathrm{~cm}$ (data not shown). Although the soil has an exceptionally high fine sand fraction of 65-77 per cent, it is probably a well-graded soil and according to Moolman \& Weber (1978) such soils do not have a high compactibility.

Root studies indicated an even distribution of roots under all the cultivation practices with no convincing differences between treatments (Plate 1). The method used to determine root distribution was not suited to reveal root rejuvenation under the deep cultivation treatment.

\section{CONCLUSIONS}

The differences found in vine performance must be ascribed mainly to the effect of weed competition for especially nitrogen and presumably also for moisture. It is clear that even with irrigation and in a soil allowing deep vine root penetration, weeds cannot be allowed to grow actively in vineyards during the growing season, especially when $\mathrm{N}$ supply is inadequate.

Combined with an active cover crop, intensive root pruning apparently had an increased negative effect on vine performance. Although deep cultivation and a cover crop improved soil physical conditions as judged by water infiltration, the expected positive effect of this on vine performance was completely overshadowed by the negative effects of severe root pruning and weed competition.

Further studies are clearly necessary to determine the optimum stage and intensity of root pruning in order to find the correct balance between the benefits of improved soil physical conditions in soils with a compaction hazard, and the possible negative effect that severe root pruning, because of a drastic soil disturbance, may have on vine performance.

\section{LITERATURE CITED}

ALTWEG, A. \& KOBLET, W., 1976. Bezichung zwischen Einsaaten und Entwicklung von Jungreben. Schweiz. Z. Obst-u. Weinb. 10, 204-211.

BEYERS, E., 1962. Diagnostic leaf analyses for deciduous fruit. S. Afr. J. Agric. Sci. 5(2), 315-329.
BLACK, A. L., 1973. Crop residue, soil water and soil fertility related to spring wheat production and quality after fallow. Soil Sci. Soc. Am. Proc. 37, 754-758.

BYRNE, M. E. \& HOWELL, G. S., 1978. Initial response of Baco Noir grapevines to pruning severity, sucker removal and weed control. Am. J. Enol. Vitic. 29, 192-198.

CHAMPAGNOL, F., 1978. Fertilisation optimale de la vigne. Progrès agric. vitic. 95 (15 et 16), 423-440.

CHRISTENSEN, L. P., KASIMATIS, A. N. \& JENSEN, F. L., 1978. Grapevine nutrition and fertilization in the San Joaquin Valley. Agric. Sci. Publications, Univ. California, Berkeley.

CHRISTENSEN, L. P. \& LYNN, C., 1969. Vineyard cover crops proving their worth. West. Fruit Grower 23 (5), 34-36.

CONRADIE, W. J., 1981. Consumption of nutrients by Chenin blanc grown in sand culture and seasonal changes in the chemical composition of leaf blades and petioles. S. Afr. J. Enol. Vitic. 2(1), 15-18.

KAISER, G., 1966. Investigations into the regeneration of the vine root system as affected by soil cultivation (Ru.). Kisérl. Közlem 59, 9-23. (Abstr.: Hort. Abstr. 40, 5907, 1970).

KOSHI, P. T. \& FRYREAR, D. W., 1973. Effect of tractor traffic and surface mulch on seedbed configuration and soil properties. Soil Sci. Soc. Am. Proc. 37, 758-762.

LITVINOV, P. I., 1967. Improvement of soil and rejuvenation of the root systems of vines in bearing plantations (Ru.). Vinodel. Vinogr. Magärac. 16, 53-69. (Abstr.: Hort. Abstr. 39, 411, 1969).

LITVINOV, P. I. \& BESKROVNYI, A. S., 1979. The effect of deep cultivation of the soil on grapevine productivity (Ru.). Vinodelie $i$ Vinogradarstvo SSSR 1, 30-32. (Abstr. Hort. Abstr. 49, 5736, 1979).

MACVICAR, C. N. \& SOIL SURVEY STAFF, 1977. Soil classification - A binomial system for South Africa. Dept. Agric. Tech. Serv., Pretoria, R.S.A.

MARCELIN, H., 1979. La vigne et l'azote. Vignes Vins. 277, 11.

MELKONJAN, A. S., MKRTCJAN, R. S. \& DAVTJAN, M. O., 1968. The effectiveness of deep cultivation of interrows in vineyards on stony soils in Armenia (Ru.). Vinodelie Vinogradarstvo 28, 24-28. (Abstr.: Hort. Abstr. 39, 4397, 1969).

MEYER, E. \& CUINIER, C., 1977. Le point sur l'enherbement des vignobles. (On cultivating vineyards with grass cover). Vignes Vins 262, 3-7.

MOOLMAN, J. H. \& WEBER, H. W. 1978. 'n Ondersoek na die bydrae van die fynsandfraksie tot die verdigbaarheid van fynsandgronde in Suid-Kaapland. Agrochemophysica 10 , 39-46.

OPREA, D. D., SEVERINE, E. \& TALOI, N., 1967. Observations on root regeneration in vines. (Swedish). Luor. sti. Inst. agron. N. Bălcescu, Series B10, 397-411. (Abstr.: Hort. Abstr. 39, 337, 1969).

RYABCHUN, O. P., 1974. Growth changes in the main grapevine roots in relation to cutting damage (Ru.). Biologicheskii Zhurnal Armenii 26, 15-23. (Abstr.: Hort. Abstr. 45, 6435, 1975).

SCHRÖDER, D., ZAKOSEK, H. \& BÖLL, K. P., 1978. Auswirkung des Hebizideinsatzes im Weinbau auf die Zellulosezerzetzung im Boden. (Effect of herbicides in vineyards on cellulose decomposition in soil). Weinberg $u$. Keller. 25, 369:375.

VAN DOREN, D. M. (Jr.) \& TRIPLETT, G. B. (Jr), 1973. Mulch and tillage relationships in corn culture. Soil Sci. Soc. Am. Proc. 37, 766-769.

VAN HUYSSTEEN, L. \& WEBER, H. W., 1980a. The effect of conventional and minimum tillage practices on some soil properties in a dryland vineyard. S. Afr. J. Enol. Vitic. 1(1), 35-45.

VAN HUYSSTEEN, L. \& WEBER, H. W., 1980b. Soil moisture conservation in dryland viticulture as affected by conventional and minimum tillage practices. S. Afr. J. Enol. Vitic. 1(2), 67-75.

VAN HUYSSTEEN, L. \& WEBER, H. W., 1980c. The effect of selected minimum and conventional tillage practices in vineyard cultivation and vine performance. S. Afr. J. Enol. Vitic. 1(2), 77-83.

VAN ZYL, J. L., 1981. Waterbehoefte en Besproeiing. In: Wingerdbou in Suid-Afrika, 234-282. Eds.: J. D. Burger \& J. Deist. V.O.R.I., 7600 Stellenbosch.

WINKLER, A. J., COOK, J. A., KLIEWER, W. M. \& LIDER, L. A., 1974. General Viticulture. Univ. Calif. Press, Berkeley.

ZEEMAN, A. S., 1981. Oplei. In: Wingerdbou in Suid-Afrika, 185-201. Eds.: J. D. Burger \& J. Deist. V.O.R.I., 7600 Stellenbosch. 